\title{
Penelusuran Mekanisme Flavonoid Kulit Jeruk Keprok (Citrus reticulata) Sebagai Agen Kemopreventif Melalui Docking Molekuler Pada Protein Target CYP1A2
}

\author{
Perdana Adhi Nugroho, Dyani P Sukamdi, Andita Pra Darma, Riris Istighfari \\ Jenie, dan Edy Meiyanto*
}

Cancer Chemoprevention Research Center

Fakultas Farmasi, Universitas Gadjah Mada, Yogyakarta

http://ccrc.farmasi.ugm.ac.id,

E-mail: meiyan_e@ugm.ac.id

\begin{abstract}
ABSTRAK
Subklas flavonoid khususnya golongan polimetoksiflavon menunjukan aktivitas kemopreventif pada berbagai sel kanker secara in vitro dan beberapa studi in vivo. Pada tahapan inisiasi kanker, bioaktivasi karsinogen polisiklik aromatik hidrokarbon secara signifikan dapat direduksi oleh senyawaan polimetoksiflavon melalui penghambatan sistem enzim sitokrom P450 (CYP) dalam level transkripsi gen maupun interaksi langsung dengan enzim tersebut. Pada tahapan promosi kanker, berbagai studi menunjukan bahwa proliferasi sel kanker dihambat lebih kuat oleh golongan metoksiflavon dibandingkan hidroksiflavon.Tangeretin, nobiletin, naringin dan hesperidin adalah beberapa senyawa polimetoksiflavon dari kulit jeruk keprok yang dilaporkan memiliki efek kemopreventif melalui modulasi aktivitas CYP1A2. Penelitian ini bertujuan untuk mengetahui afinitas, konformasi dan interaksi senyawa berkerangka polimetoksiflavon kulit jeruk keprok (Citrus reticulata) terhadap protein target CYP1A2 menggunakan molecular docking. Optimasi geometri struktur polimetoksiflavon dilakukan dengan piranti lunak Molecular Operating Environment for Windows. Konformasi optimum struktur polimetoksiflavon dihasilkan menggunakan metode semiempirik AMBER99. Kemudian dilakukan proses docking senyawa uji dengan bindingsite CYPIA2 (PDB ID : 2HI4) menggunakan piranti lunak Molecular Operating Environment for Windows dalam kondisi tanpa air. Hasil docking senyawa golongan polimetoksiflavon dibandingkan dengan native ligan pada target CYP1A2, menunjukkan interaksi polimetoksiflavon yang lebih kuat dibanding interaksi ligan pembanding á-naphtoflavon.
\end{abstract}

Kata kunci : Citrus reticulata, polimetoksiflavon, molecular docking, CYP1A2

\section{PENDAHULUAN}

Salah satu bahan alam yang berpotensi sebagai bahan kemopreventif adalah kulit jeruk Keprok (Citrus reticulata). Kulit jeruk keprok banyak mengandung senyawa polimetoksiflavon seperti tangeretin, nobiletin, sinensetin dan hesperetin (Nogata et al., 2006). Senyawa flavon secara umum telah banyak diteliti manfaatnya untuk peningkatan kesehatan dan pencegahan penyakit kanker serta memiliki kelebihan berupa toksisitas yang sangat rendah dan bioavailabilitasnya yang stabil (Wen et al., 2006 ${ }^{\text {a }}$. Efek kemopreventif dari flavon ini diduga melalui mekanisme modulasi aktivitas enzimatik tubuh untuk mengurangi karsinogenisitas dari senyawaan xenobiotik (Walle, 2007). Salah satunya adalah melalui modulasi sistem enzim sitokrom P450 (CYP) yang berperan dalam aktivasi prokarsinogen menjadi metabolit reaktif karsinogenik.

Beberapa flavonoid dapat mengubah sistem CYP melalui pengikatan pada Aril Hidrokarbon Reseptor (AhR), suatu faktor transkripsi teraktivasi ligan dari CYP (Zhang et al., 2003). Inhibisi kompetitif tipe CYP enzim seperti CYP 1A1, 1A2, 2E1 dan 3A4 oleh flavon (chrysin, baecalin, dan galangin) juga telah banyak dilaporkan (Wen et al., 2005 dan Moon et al., 2006). Dalam 
penelitian ini digunakan kompleks enzim CYP1A2. Menurut penelitian (Zhai, 1998), aktivitas CYP1A2 secara in vitro dapat diinhibisi oleh flavonoid sehingga dapat menghambat aktivasi substrat prokarsinogen menjadi karsinogen.

Berbagai studi laboratorium, investigasi epidemiologi, dan uji klinis pada manusia juga semakin mengindikasikan bahwa senyawa flavonoid berperan penting sebagai agen kemopreventif melalui mekanisme induksi apoptosis, antiproliferasi, cell cycle arrest, inhibisi angiogenesis, antioksidan, serta inaktivasi karsinogen (Ren et al., 2003). Namun kompleksnya berbagai prediksi mekanisme kemopreventif dari flavonoid membuat aktivitas kemopreventif dari flavonoid menjadi unik. Seiring dengan perkembangan ilmu dan teknologi, lahirlah bioinformatika yang merupakan aplikasi dari metode komputasi (in silico) dan analisis untuk menangkap dan menginterpretasikan datadata biologi. Salah satu cakupan dari bioinformatika adalah metode molecular docking yang mampu memperkirakan interaksi senyawa pada konformasi dan pose spesifik dengan suatu enzim atau reseptor secara lebih cepat dan efisien (Utama, 2003).

Sejauh ini belum terdapat penelitian mengenai prediksi salah satu mekanisme senyawa polimetoksiflavon kulit C. reticulata sebagai chemopreventive agent melalui simulasi docking terhadap protein target CYP1A2. Penelitian ini bermanfaat untuk membuktikan efek kemopreventif senyawa polimetoksiflavon kulit C. reticulata melalui inhibisi protein target CYP1A2 secara docking molekuler. Hasil penelitian ini dapat dijadikan landasan ilmiah mengenai kemungkinan salah satu mekanisme kemopreventif dari polimetoksiflavon kulit C. reticulata melalui gambaran afinitas, konformasi, dan interaksi pada CYP1A2 secara in silico.

\section{BAHAN DAN METODOLOGI PENELITIAN \\ Bahan}

Struktur kompleks protein crystallized human microsomal CYP1A2 yang didapatkan dari Protein Data Bank (PDB) didownload dari situs http://www.rcsb.org/ $\mathrm{pdb} /$. Struktur senyawa uji polimetoksiflavon dari kulit Citrus reticulata diperoleh dari database senyawa www.ncbi.org dalam bentuk 2 dimensi.

\begin{abstract}
Alat
Perangkat keras berupa satu set komputer dengan Windows XP Operating System. Perangkat lunak yang digunakan adalah Molecular Operating Environment (MOE) untuk docking senyawa uji dengan protein target CYP1A2.
\end{abstract}

\section{Metode Docking}

Optimasi Geometri

Senyawa-senyawa polimetoksiflavon dalam kulit jeruk keprok dibuat struktur tiga dimensi (3D) menggunakan program Molecular Operating Environment (MOE). Sudut torsi substituen pada residu benzena dioptimasi dengan metode AMBER 99. Struktur yang terbentuk dioptimasi geometri dengan pencarian secara Stochastic Search menggunakan metode semi empirik PM3 dengan algoritma Polak-Ribiere untuk mendapatkan struktur dengan energi paling stabil. Batas konvergensi ditentukan setelah tercapai gradien $0,01 \mathrm{kkal} / \mathrm{L}$ mol. Struktur stabil hasil optimasi yang didapat dimasukan dalam suatu database ligan uji, untuk kemudian di-docking-kan pada protein target.

\section{Validasi}

File kompleks protein CYP1A2 hasil download dari www.rcsb.org, dilakukan preparasi reseptor. Preparasi meliputi penghilangan air dan kofaktor. Kalkulasi jumlah muatan parsial dipilih metode AMBER99 yang spesifik untuk protein. Selanjutnya dilakukan protonated 3D agar kondisi percobaan sesuai kondisi fisiologis tubuh. Validasi penetapan binding site dilakukan berdasarkan pocket ligan dengan melakukan superpose konformasi, prinsipnya mengarahkan ligan uji pada pocket yang secara eksperimental ditempati native ligan. Parameter validitas metode digunakan RMSD (Root Mean Square Deviation). Software dikatakan memenuhi syarat validitas jika nilai RMSD kurang dari 2.

Docking Ligan Eksperimental dan Ligan Uji 
Pada penelitian digunakan struktur dari Brookhaven Protein Databank yang sudah mengandung cocrystallized ligan asli (native ligan). Docking senyawa dilakukan pada reseptor yang telah dipreparasi. Ligan uji polimetoksiflavon meliputi tangeretin, nobiletin, naringin, hesperidin yang sudah dimasukan dalam database ligan di-dockingkan pada CYP1A2. Dari tahap ini akan dihasilkan konformasi docking senyawa ligan beserta score ikatan dengan iterasi 30 kali. Output yang dihasilkan ditampilkan dalam bentuk_.mdb dengan pilihan docking pada kondisi site ligan: pocket atom dan ligan: $m d b$ file.

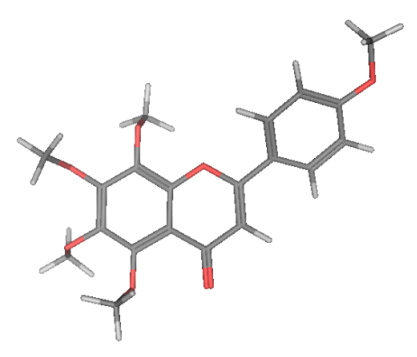

$\mathbf{A}$

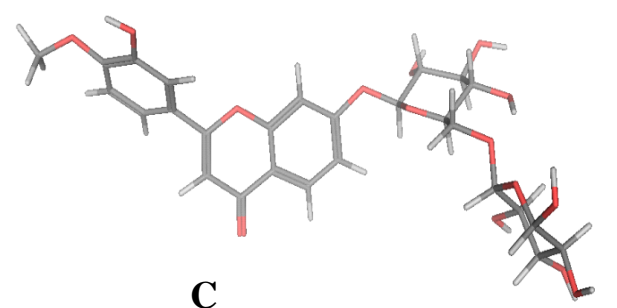

yang dipilih berdasarkan konformasi yang berada di surface binding site tersebut.

\section{HASIL dan PEMBAHASAN Optimasi Geometri}

Optimasi geometri dilakukan untuk menemukan struktur molekul yang stabil dengan energi potensial terendah. Dalam penelitian dilakukan optimasi dengan PM3 karena senyawa uji merupakan senyawa organik dan mempunyai cincin aromatik.

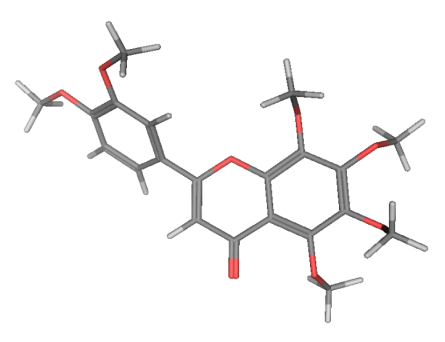

B

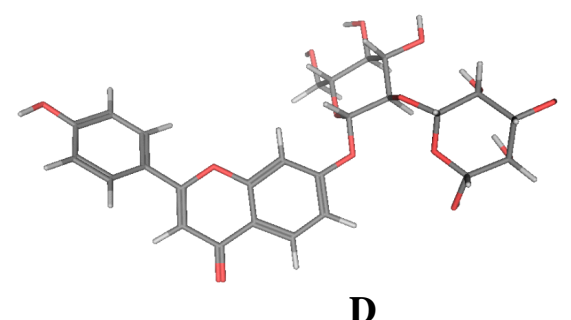

Gambar 1. Struktur 3D hasil optimasi geometri : (A) Tangeretin (B) Nobiletin (C) Hesperidin (D) Naringin. Warna abu-abu menunjukan rantai karbon, putih adalah hidrogen dan merah adalah atom oksigen

Score hasil docking akan ditampilkan dalam bentuk database viewer yang dapat dieksport dalam bentuk _.xls. Penampilan hasil interaksi dapat ditampilkan dalam bentuk 2D ataupun 3D. Interaksi Ligan uji dan ligan eksperimental pada protein target dibandingkan hingga didapatkan pose dan konformasi simetri yang nantinya dapat digunakan sebagai pose interaksi yang logis secara kimia dan biologi. Keputusan pengambilan pose dilakukan pada iterasi yang menghasilkan posisi ligan berada di binding site dan bukan di luar binding site dan bukan diluar surface binding site. Penentuan score dipilih berdasarkan iterasi

\section{Validasi}

Tahap validasi dilakukan untuk mengkalibrasi metode docking pada software yang digunakan. Proses validasi ini dibandingkan antara posisi native ligan terhadap reseptor yang telah diuji secara eksperimental. Metode yang dipakai untuk docking yaitu sesuai hasil validasi yang dilakukan berdasarkan parameter RMSD. Metode dikatakan valid jika RMSD <2, artinya posisi ligan copy setelah superpose semakin dekat posisinya menduduki native ligan (Cole et al., 2005). Nilai RMSD dipengaruhi juga oleh resolusi kompleks protein reseptor ketika pengambilan struktur pemodelan. Dalam percobaan digunakan 
kompleks 2HI4 untuk tahap docking selanjutnya karena memiliki RMSD yang lebih rendah.
Jika dibandingkan interaksi ligan senyawa aglikon polimetoksiflavon, hasil docking antara nobiletin dan tangeretin

Tabel 1. Data validasi interaksi antara ligan dengan reseptornya

\begin{tabular}{lclc}
\hline Protein Target (PDB ID/kompleks) & RMSD \pm SD & Metode Eksperimental & Resolusi \\
\hline 1TQN/CYP3A4-BHF & $1,298 \pm 0,413$ & Difraksi X-Ray & $2,05 \AA$ \\
2HI4/CYP1A2-BHF & $0,544 \pm 0,611$ & Difraksi X-Ray & $1,95 \AA$ \\
\hline
\end{tabular}

\section{Docking Senyawa Uji}

Senyawa uji di-dockingkan pada protein target CYP1A2 yang erat kaitannya dengan aktivasi karsinogen. Semakin kecil harga scoring, ikatan ligan dengan respetor akan semakin stabil. Nilai scoring juga bisa dinyatakan dalam konstanta inhibisi (Ki) yang merupakan fungsi dari temperatur. Temperatur yang digunakan dalam perhitungan sesuai kondisi fisiologis manusia yaitu $37^{\circ} \mathrm{C}\left(310^{\circ} \mathrm{K}\right)$

Telah dilakukan docking senyawa uji polimetoksiflavon pada bindingsite ánaphtoflavon yang merupakan native ligan inhibitor dalam protein target CYP1A2. Analisis dilakukan dengan membandingkan ligan uji dengan native ligan. Hasil menunjukan bahwa ikatan semua senyawa uji memiliki nilai Ki yang lebih kecil dari native ligan á-naphtoflavon, yang berarti semua senyawa uji (polimetoksiflavon) mempunyai kemampuan berikatan lebih stabil terhadap protein target CYP1A2. Dari keempat senyawa uji polimetoksiflavon, ternyata tangeretin memiliki interaksi paling kuat yaitu sekitar 80 kali kekuatan interaksi native ligan á-naphtoflavon-CYP1A2 (Tabel 2) dengan CYP1A2 (Tabel 2) menghasilkan skor yang nilainya lebih rendah daripada interaksi native ligan inhibitor ánaphtoflavon-CYP1A2. Hal ini menunjukkan bahwa ikatan antara polimetoksiflavon dengan CYP1A2 lebih stabil sehingga diprediksikan memerlukan aktivitas inhibisi polimetoksiflavon terhadap CYP1A2 lebih tinggi. Sementara pada glikosida flavanon, naringin memberikan scoring sedikit berbeda dengan tangeretin namun tetap lebih rendah dibandingkan á naphtoflavon (Tabel 2). Ini memberikan gambaran bahwa flavonoid dalam bentuk aglikon dan bentuk glikosida sama-sama diprediksikan memiliki aktivitas inhibisi CYP1A2 yang tinggi.

Senyawa uji berinteraksi dengan reseptor melalui berbagai ikatan. Analisis hasil terhadap interaksi ligan mampu menunjukan berbagai ikatan yang terjadi antara ligan dengan protein target. Parameter scoring, ditentukan oleh kekuatan ikatan, jenis ikatan dan kesesuaian pose dengan $\mathrm{na}$ tive ligan. Score merupakan jumlah kekuatan ikatan Van der Walls, ikatan hidrogen, interaksi antar atom polar-polar dan polarnonpolar, ikatan hidrofobik dengan menambah pengaruh torsi ikatan dan

Tabel 2. Hasil score docking dan Ki ligan pada CYP1A2

\begin{tabular}{|c|c|c|}
\hline Senyawa & $\begin{array}{l}\text { Score CYP1A2-BHF } \\
\text { (kkal) }\end{array}$ & $\begin{array}{l}\mathrm{Ki} \\
(\mathrm{nM})\end{array}$ \\
\hline Native ligan ( $\boldsymbol{\alpha}$-naphtoflavon) & $-10,2616$ & 62,228 \\
\hline Tangeretin (pentametoksiflavon) & $-12,9962$ & 0,747 \\
\hline Nobiletin (hexametoksifavon) & $-11,6735$ & 6,346 \\
\hline Hesperidin (glikosida metoksi flavanon) & $-10,3257$ & 56,102 \\
\hline Naringin (glikosida flavanon) & $-12,5250$ & 1,601 \\
\hline
\end{tabular}

penurunan induksi. Semakin rendah score, maka ikatan antara ligan dan protein semakin stabil dan semakin meningkat afinitasnya. 
Berdasarkan penelitian diperoleh hasil bahwa tangeretin yang memiliki score paling rendah (Tabel 2) ternyata memiliki nilai kekuatan ikatan dan jumlah ikatan hidrogen yang paling banyak pula (Tabel 3 ).
Jumlah nilai kekuatan ikatan yang makin besar menunjukan interaksi lebih kuat dan stabil, hal ini dibuktikan dengan korelasi antara rendahnya score dengan banyaknya ikatan hidrogen (Gambar 2).

Tabel 3. Hasil intrepretasi interaksi dan jenis ikatan berbagai ligan pada CYP1A2

\begin{tabular}{|c|c|c|c|}
\hline Senyawa & Jenis Ikatan & $\begin{array}{l}\text { Residu asam } \\
\text { amino yang } \\
\text { berikatan }\end{array}$ & $\begin{array}{l}\text { Gugus yang } \\
\text { berinteraksi }\end{array}$ \\
\hline $\begin{array}{l}\text { Native ligan } \\
\text { Naftalen } \\
\boldsymbol{\alpha} \text {-naphtoflavon }\end{array}$ & Transfer muatan awan elektron molekul & PHE 226 & Cincin $\mathrm{A}$ \\
\hline Tangeretin & $\begin{array}{l}2 \text { Ikatan hidrogen } \\
\text { Transfer Muatan awan elektron molekul }\end{array}$ & $\begin{array}{l}\text { ILE } 386 \\
\text { THR } 321 \\
\text { PHE } 226\end{array}$ & $\begin{array}{l}-\mathrm{OCH}_{3} \\
-\mathrm{OCH}_{3} \\
\text { Cincin B Benzena }\end{array}$ \\
\hline Nobiletin & $\begin{array}{l}\text { Transfer Muatan awan elektron molekul } \\
1 \text { Ikatan Hidrogen }\end{array}$ & $\begin{array}{l}\text { PHE } 226 \\
\text { THR } 124\end{array}$ & $\begin{array}{l}\text { Cincin B Benzena } \\
-\mathrm{OCH}_{3}\end{array}$ \\
\hline Naringin & $\begin{array}{l}2 \text { Transfer Muatan awan elektron molekul } \\
1 \text { Ikatan Hidrogen }\end{array}$ & $\begin{array}{l}\text { PHE } 226 \\
\text { PHE } 260 \\
\text { ILE } 314\end{array}$ & - O Cincin Piran \\
\hline$\overline{\text { Hesperidin }}$ & 2 Ikatan Hidrogen & $\begin{array}{l}\text { ARG } 108 \\
\text { THR } 124\end{array}$ & $\begin{array}{l}-\mathrm{OH} \\
\mathrm{C}=\mathrm{O} \text { Cincin }\end{array}$ \\
\hline
\end{tabular}

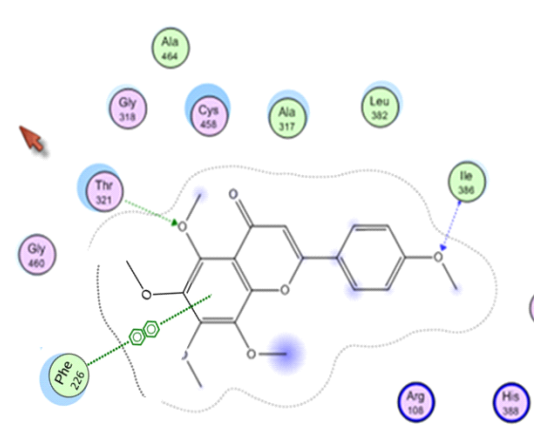

A

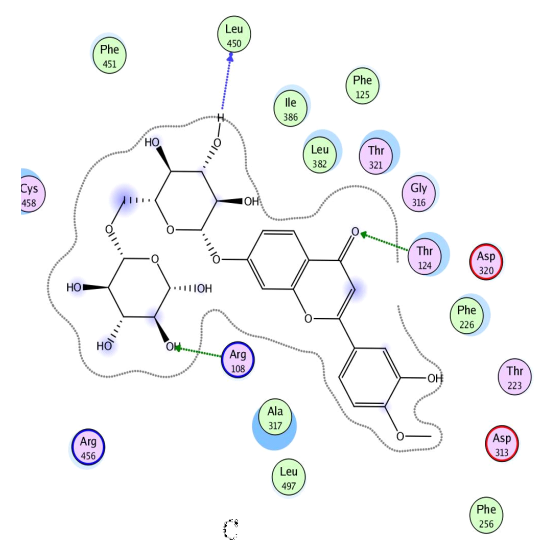

(iii)

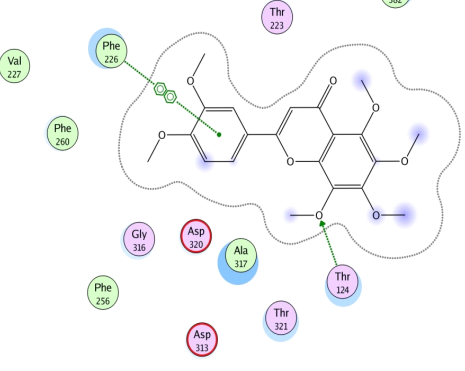

$\mathbf{B}$

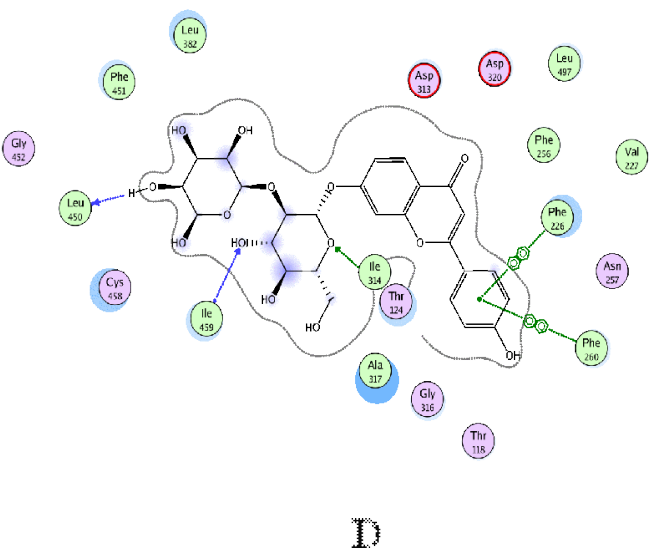

Gambar 2. Interaksi 2 Dimensi Senyawa Uji pada binding site a-naphtoflavon dalam pocket CYP1A2: (A) Tangeretin (B) Nobiletin (C) Hesperidin (D) Naringin. Tanda panah menunjukan jenis ikatan residu asam amino CYP1A2 yang berinteraksi dengan struktur senyawa uji 
Pada proses docking, dari berbagai prediksi pose dan konformasi ikatan ligan uji polimetoksiflavon terhadap protein target CYP1A2 harus dipilih konformasi yang simetri secara 3 dimensi dengan pose docking native ligan á-naphtoflavon (Gambar 3) agar kalkulasi komputasional yang dilakukan untuk senyawa uji sesuai dengan kalkulasi konformasi native ligan sebagai inhibitor CYP1A2. Hal yang sama berlaku pada saat penentuan posisi ikatan ligan uji secara 3 dimensi sehingga dari proses ini akan diperoleh data berupa score representatif yang menggambarkan konformasi inhibisi senyawa uji terhadap CYP1A2. Berdasarkan percobaan, tangeretin secara komputasional memiliki interaksi dalam konformasi inhibisi CYP1A2 jauh lebih kuat dibandingkan native ligan á -naphtoflavon.

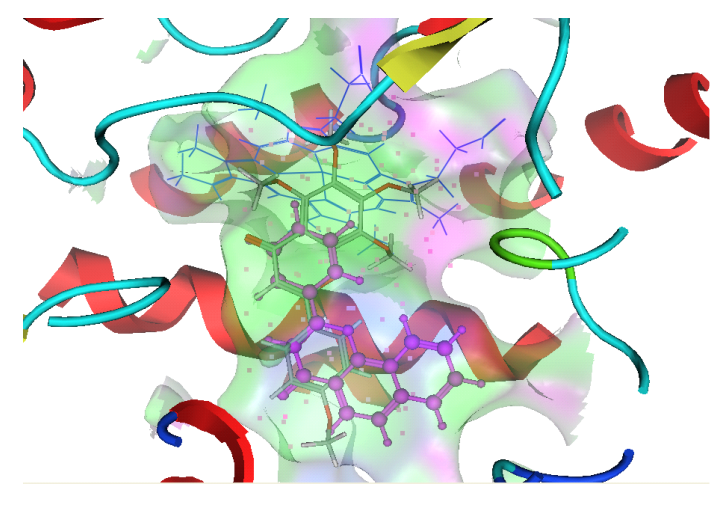

(A)

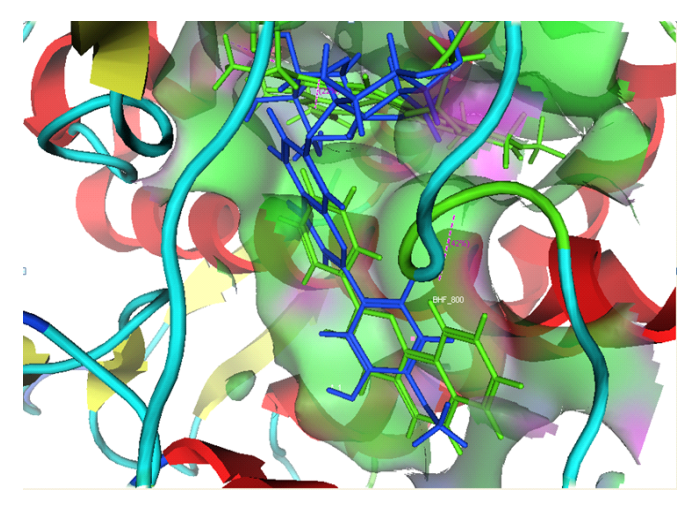

(C)
Ligan á-naphtoflavon sendiri merupakan ligan asli yang telah dikenal luas sebagai inhibitor CYP1A1 dan CYP1A2 dengan mekanisme inhibisi nonkompetitif (Martignoni, 2006). Oleh karenanya diprediksikan score docking senyawa tersebut dengan CYP1A2 memiliki energi yang rendah. Dengan ditemukannya fakta komputasional bahwa score docking tangeretin paling rendah, jauh dibandingkan ligan pembanding á-naphtoflavon. Hal ini menunjukan bahwa ikatan tangeretin dengan CYP1A2 lebih stabil dan kuat dibandingkan dengan native ligan á -naphtoflavon.

Fakta tersebut sejalan dengan penelitian in vitro dan in vivo (Walle, 2007) yang menyatakan bahwa senyawaan metoksiflavon dengan jumlah gugus metoksi yang optimal dapat berperan sebagai

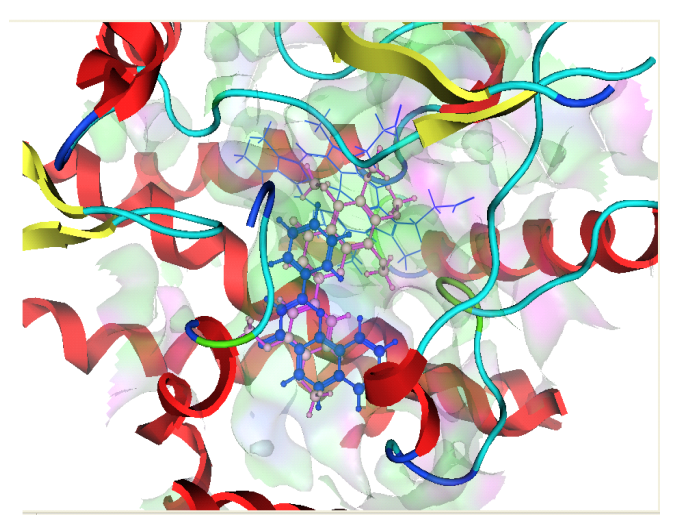

(B)

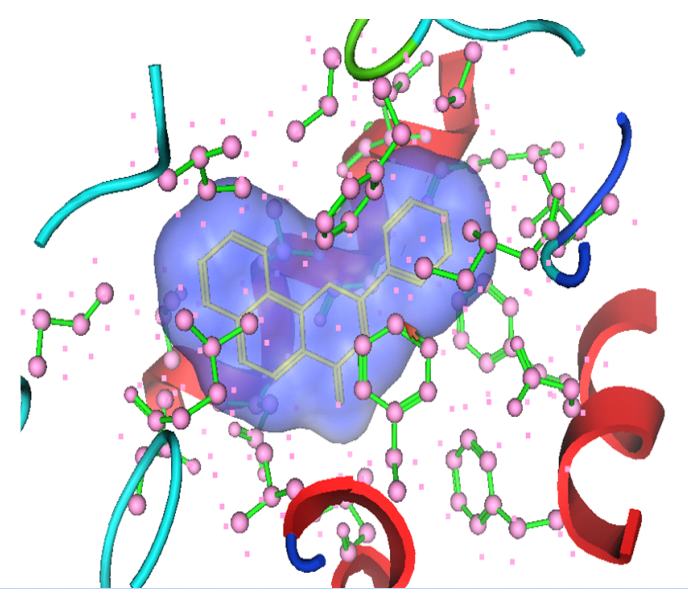

(D)

Gambar 3. Interaksi 3 Dimensi Senyawa Uji pada binding site $\alpha$-naphtoflavon dalam pocket CYP1A2: (A) Tangeretin (B) Nobiletin (C) Hesperidin (D) Naringin. Struktur senyawa uji diposisikan simetri dengan native ligan untuk mendapatkan suatu konformasi inhibisi dari CYP1A2 sehingga didapatkan hasil docking yang logis dan representatif 
inhibitor CYP1A2 baik dalam skala transkripsi ataupun dalam tingkatan protein. Hasil penelitian ini mendukung teori bahwa senyawaan polimetoksiflavon dalam kulit Citrus reticulata dapat menghambat aktivitas CYP1A2 di hepar yang telah diketahui dapat mengaktivasi senyawa prokarsinogen (benzo(a)pyrene) menjadi intermediet reaktif karsinogenik (diol epoksida). Oleh karenanya kemungkinan mekanisme unik dari polimetoksiflavon sebagai agen kemopreventif cenderung mengarah pada penghambatan aktivasi senyawaan karsinogenik melalui penghambatan CYP1A2.

Selain itu, hasil penelitian ini secara in silico membuktikan bahwa flavonoid termetilasi lebih aplikatif digunakan secara klinis sebagai agen kemopreventif dibandingkan polifenol dan hidroksiflavon (Walle, 2007). Hal ini terkait dengan bioavailabilitasnya yang lebih tinggi, terlindungi dari metabolisme cepat di hepar serta mengingat adanya proses hidrolisis glikosida flavonoid menjadi aglikon flavonoid pada mukosa mulut dan usus (Williamson, 2005, Wen et al, 2006 ${ }^{\mathrm{a}}$, Wen et al, 2006 ${ }^{\mathrm{b}}$ dan Walle et al, 2007). Fakta tersebut terbukti secara kalkulasi komputasi bahwa aglikon termetilasi seperti tangeretin memiliki afinitas dalam konformasi inhibisi pada protein target CYP1A2 lebih kuat dibandingkan glukosida flavonoid seperti hesperidin dan naringin. Sehingga kemungkinan flavonoid yang aktif dalam penggunaan sebagai agen kemopreventif secara oral pada manusia adalah aglikon flavonoid. Kemungkinan-kemungkinan mekanisme diatas masih perlu diteliti lebih lanjut. Oleh karena itu, pengembangan flavonoid sebagai agen antikanker yang diarahkan pada penelitian-penelitian senyawa polimetoksiflavon perlu ditindaklanjuti.

\section{KESIMPULAN}

Hasil penelitian menunjukkan bahwa senyawa polimetoksiflavon dalam kulit jeruk keprok (Citrus reticulata) khususnya tangeritin memiliki afinitas yang lebih kuat sebagai inhibitor CYP1A2 dibandingkan native ligan á -naphtoflavon

\section{UCAPAN TERIMAKASIH}

DP2M DIKTI yang telah membantu mendanai penelitian ini melalui program PKM 2008.

\section{DAFTAR PUSTAKA}

Cole, J.C., Murray, C.W., Nissink, J.W.M., Taylor, R.D., and Taylor, R., 2005, Comparing Protein-Ligand Docking Program Is Difficult, Proteins, 60: 325-332.

Martignoni M., Groothuis GM, dan de Kanter R., 2006, Species differences between mouse, rat, dog, monkey and human CYP-mediated drug metabolism, inhibition and induction., Expert Opin Drug Metab Toxicol. 2(6):875-94.

Moriguchi, T., Kitai, M., Hasegawa, S., and Omur, M. 2003. 'Molecular approach to citrus flavonoid and limonoid biosynthesis', Food, Agriculture \& Environment, 1(1): 22-25.

Moon, Y.J., Wang X, and Morris, M.E., 2005, Dietary flavonoids: Effects on xenobiotic and carcinogen metabolism, Toxicology in Vitro Mini Reviews, 20, 187-210.

Nogata, Y., Sakamoto, K., Shiratsuci, H., Ishii, T., Yano, $\mathrm{M}$ and Ohta, H., 2006, Flavonoid Composition of Fruit Tissues of Citrus Species, Biosci.Biotechnol.Biochem, 70(1): 178-192.

Ren, W., Zhenhua, Q., Hongwei, W., Lei, Z., and Li, Z., 2003, 'Flavonoids: Promising Anticancer Agents', Medicinal Research Reviews , 23(4): 519-534.

Utama, 2003, Peranan Bioinformatika dalam Dunia Kedokteran, UI Press: Jakarta.

Walle, T., 2007, Methoxylatedflavones, a superior cancer chemopreventive flavonoid subclass?, Seminars in Cancer Biology, 17: 354-362

Walle T., Otake Y, Brubaker JA, Walle UK, 
and Halushka PV, 2001, Disposition and metabolism of the flavonoid chrysin in normal volunteers. $\mathrm{Br} J$ Clin Pharmacol., 51:143-146.

Walle, T., Ta N., Kawamori T., Wen X., Tsuji P.A., and Walle U.K., 2007, Cancer chemopreventive properties of orally bioavailable flavonoidsmethylated versus unmethylated flavones. Biochem Pharmacol., 73:1288-1296.

Wen X and Walle T., 2006 ${ }^{\mathrm{a}}$, Methylated flavonoids have greatly improved intestinal absorption and metabolic stability. Drug Metab Dispos., 34:1786-1792.

Wen X and Walle T., 2006 ${ }^{\mathrm{b}}$, Methylation protects dietary flavonoids from rapid hepatic metabolism. Xenobiotica, 36:387-397.

Wen X, Walle UK, and Walle, T., 2005, 5,7Dimethoxyflavone down-regulates CYP1A1 expression and benzo[a]pyrene-induced DNA binding in Hep $\mathrm{G} 2$ cells. Carcinogenesis, 26:803-809.

Williamson, G., and Manach, C., 2005, Bioavailability and bioefficacy of polyphenols in humans. II. Review of 93 intervention studies. Am J Clin Nutr., 81:243S-255S.

Zhai S., Dai R., Friedman F. K., and Vestal R. E., 1998, Comparative Inhibition of Human Cytochromes P450 1A1 and $1 \mathrm{~A} 2$ by Flavonoids, The American Society for Pharmacology and Experimental Therapeutics, 26 (10), 889-992.

Zhang S, Qin C, and Safe S., 2003, Flavonoids as aryl hydrocarbon receptor agonists/antagonists: effects of structure and cell context. Environ Health Perspect; 111:1877-82. 